\title{
Social Media Utilization by Millenial Generation in Order to Support Radicalism Spirit Counter
}

\author{
Gerald Theodorus L. Thoruan \\ Research and Development Agency Ministry of Defence \\ Indonesia \\ theodorus_recht@yahoo.com
}

\begin{abstract}
Nowadays in globalization era whereas technology develop fastly and everybody can use it to access information easily. In digital era nowadays, conventional media still exist but in this era has been abandoned by the generation which born in digital era, they are millennial generation. Media which they used today whereas in this media they can do anything, nowadays hopefully social media utilized to something positive. One thing that positively can done is to utilized social media in order to support radicalism counter script. This is urgently done because nowadays radicalism group using social media to spread their propaganda to every people and this group want what they have spreader accepted by whole people which is lack of knowledge. This research used descriptive qualitative method with phenomenology approach and collecting data with library research. The data resources which had been used is with secondary data such as library, internet news, journal, etc. The recommendation in this paper is there is social media utilization model for millennial generation in order to support script radicalism counter.
\end{abstract}

Keywords-milenial generation; script radicalism counter; social media.

\section{INTRODUCTION}

Millennial generation term nowadays often heard on public society. These term came from millennial which made by two historical expert and an American author, William Strauss and Neil Howe in their few books. Millennial generation or $\mathrm{Y}$ generation also familiar sounded me generation or echo boomers. Study about millennial generation, primarily at America has been done so much. Such as study which has been done by Boston Consulting Group (BCG) together with University of Berkley 2011 which theme American Millennial: Deciphering the Enigma Generation [1]. The previous year 2010, Pew Research Center also released research report with title Millennial: A Portrait of Generation Next. Based on that research these are the characteristic those millennial generations: (1) Millennial prefer trust with user generated content than one way information, (2) Millennial prefer gadget than TV, (3) Millennial obligatory have social media, (4) Millennial don't like read conventionally, (5) Millennial know technology better than their parents, (6) Millennial unloyal but working effectively, (7) Millennial prefer do some transaction with cashless [2].

Tetra Pal Index report 2017 said that there were approximately 132 million internet user in Indonesia, while almost the half around $40 \%$ are social media user. There was an inflation compare with 2016 whereas there were an improvement around $51 \%$ or around 45 million internet active user, followed by development around $34 \%$ social media user. While that social media user through gadget are on $39 \%$.

Internet user in Indonesia dominated by millennial generation and $\mathrm{Z}$ generation; the generation which born on digital era, whereas smartphone used to anything activity, one of that for social media.

Based on AdAge, millennial more often spending approximately 25 hours every week for surfing on internet. This generation prefer exploring blog, website and social media. They prefer to share, gives likes, also give comment to all the founded content. Quoted from Hubspot, 65\% millennial generation directly facing with other peoples for social aim or for private aim through social media, such as Twitter, Instagram or Facebook. While that, survey which had been done by APJII (Asosiasi Penyelenggara Jasa Internet Indonesia) there were three social media that often been visited such as Facebook, Instagram and Youtube [3].

Social media not only for socialization, business, can also been used by some groups to distributing radicalism. This situation which must be beware nowadays. There are so many young people who easily impacted by news content which on social media and also they can be doctrinized with the ideology which contradictive to Pancasila. This had been proved with so many existing hoax news on social media nowadays and there was so many suspect who had caught by Police

In this case to counter so many hoax or radicalism which on social media, millennial generation have important role as an agent to countering radicalism with campaigning or clarifying ideology which unmatching to Indonesia state ideology.

\section{RESEARCH METHOD}

This research used descriptive qualitative method with phenomenology approach and data collected by library research. Then the data resources which had been used is with secondary data such as library, internet news, journal, etc.

\section{RESULTS AND DISCUSSION}

The development of information and technology nowadays, utilized by some unresponsible group. The existing hate speech 
on internet can't separated with intolerant and radical group. This group always try to make Indonesia unstable and unconducive. They also try to make the build tolerant become intolerant. The fact is nowadays young people easily say infidel just because their friend has different religion. What's the effect? This generation change to the easily anger generation, if they faced something that they thought unmatched. That anger then provoked some community to do vandalism. Persecution act, street judging, mutually throwing often colouring this nation. When provocative radicalism still happened, millennial generation also must active to promoting peace messages. That thing done for can be narrative countering related to hate speech. Promoting peace message must be do with variative style. It can be written status, made meme, until writing many script on social media. If that needed made a vlog which content are peace messages. This thing is important in order to didn't forget our history. Because Indonesian character are friendly, helpfully and respectfully. This positive thing that makes Indonesia strong and different with other nations.

\section{CONCLUSION}

The research conclusion is social media effectively and have a benefit to countering radicalism which existed on internet, countering with the promoting peace message which would establish one Indonesia nation.

\section{REFERENCES}

[1] http://www.republika.co.id/berita/koran/inovasi/16/12/26/ois64613mengenal-generasi-millennial.

[2] https://student.cnnindonesia.com/edukasi/20160823145217-445 153268/generasi-millenial-dan-karakteristiknya/

[3] APJII Report 2016. 